\title{
Pengaruh Kesadaran Wajib Pajak, Sanksi Perpajakan, E-Filing, dan Tax Amnesty Terhadap Kepatuhan Pelaporan Wajib Pajak
}

\author{
Luh Putu Santi Krisna Dewi ${ }^{1}$ \\ Ni Ketut Lely Aryani Merkusiwati ${ }^{2}$
}

${ }^{1}$ Fakultas Ekonomi dan Bisnis Universitas Udayana (Unud), Bali, Indonesia
email: santikrisna96@gmail.com/ Telp: +6281237244664
${ }^{2}$ Fakultas Ekonomi dan Bisnis Universitas Udayana (Unud), Bali, Indonesia

\begin{abstract}
ABSTRAK
Tujuan dari penelitian ini adalah untuk mengetahui pengaruh kesadaran wajib pajak, sanksi perpajakan, penerapan sistem e-filing, dan pengetahuan tax amnesty terhadap kepatuhan pelaporan wajib pajak orang pribadi di Kantor Pelayanan Pajak Pratama Denpasar Timur. Populasi penelitian adalah wajib pajak orang pribadi yang terdaftar di Kantor Pelayanan Pajak Pratama Denpasar Timur dan penentuan sampel menggunakan metode non probability sampling dengan teknik purposive sampling.Penelitian ini menggunakan sampel sebanyak 100 responden yang dihitung menggunakan rumus Slovin.Pengumpulan data dilakukan dengan kuesioner yang diukur dengan skala likert.Hasil penelitian ini menunjukkan bahwa kesadaran wajib pajak, sanksi perpajakan, penerapan sistem $e$-filing, dan pengetahuan tax amnesty berpengaruh positif terhadap kepatuhan pelaporan wajib pajak orang pribadi di Kantor Pelayanan Pajak Pratama Denpasar Timur.
\end{abstract}

Kata kunci: Wajib pajak,e-filing, tax amnesty, kepatuhan wajib pajak

\begin{abstract}
ABSTRACK
The aims of the current study are to determine the effect of taxpayer awareness, tax sanctions, the application of e-filing system, and the knowledge about tax amnesty on the personal taxpayer reporting compliance in the East Denpasar Tax Office. The population of this study was conducted on personal taxpayer registered in the East Denpasar Tax Office. Non probability sampling method and purposive sampling technique were applied to determine the samples. The numbers of samples used were 100 respondents calculated using Slovin formula. The data were collected by questionnaire measured by likert scale. The result of the current study shows that taxpayer awareness, tax sanctions, the application of e-filing system, and the knowledge about tax amnesty have a positive and significant impact on the personal taxpayer reporting compliance in the East Denpasar Tax Office.
\end{abstract}

Keyword: Taxpayer, e-filing, tax amnesty, taxpayer compliance

\section{PENDAHULUAN}

Pajak merupakan iuran yang dibayarkan oleh rakyat kepada negara yang masuk dalam kas negara yang melaksanaannya mengacu pada undang - undang serta pelaksanaannya dapat dipaksakan tanpa adanya balas jasa.Iuran tersebut digunakan oleh negara untuk melakukan pembayaran atas kepentingan umum (Mardiasmo, 2016:3). Kepedulian dalam membayar pajak akan sulit diwujudkan 
apabila dalam pengertian pajak tidak ada unsur dapat dipaksakan. Unsur ini memberikan pemahaman bahwa masyarakat dituntut untuk membayar pajak secara sukarela dan penuh kesadaran sebagai warganegara yang baik.Penerimaan pajak adalah salah satu sumber terbesar yang menyumbang pendapatan nasional.Penerimaan pendapatan negara pada tahun 2016 disajikan pada Tabel 1 berikut.

Tabel 1.

Pendapatan Negara Tahun 2016

\begin{tabular}{ccc}
\hline Sumber Penerimaan Negara & $\begin{array}{c}\text { Jumlah Penerimaan (Triliun } \\
\text { Rupiah) }\end{array}$ & Penerimaan (\%) \\
\hline Pajak & $1.546,6$ & $84,9 \%$ \\
PNBP & 273,8 & $15,0 \%$ \\
Hibah & 2,0 & $0,1 \%$ \\
\hline
\end{tabular}

Sumber: www.data-apbn.kemenkeu.go.id

Berdasarkan Tabel 1 dapat dilihat bahwa sumber penerimaan pajak adalah yang terbesar, yaitu sebesar $84,9 \%$ lalu diikuti oleh penerimaan negara bukan pajak (PNBP) sebesar 15,0\%, dan hibah sebesar 0,1\%. Menurut Togler (2005), mendorong tingkat kepatuhan wajib pajak merupakan salah satu masalah yang paling serius bagi para pembuat kebijakan.

Terancamnya upaya pemerintah untuk meningkatkan kesejahteraan dikarenakan tingkat kepatuhan pajak secara tidak langsung memengaruhi ketersediaan pendapatan untuk belanja negara (Jung, 1999).Sebagai salah satu unsur penerimaan negara, pajak memiliki peran yang sangat besar dan semakin diandalkan untuk kepentingan pembangunan dan pengeluaran pemerintahan (Supadmi, 2009).Pembangunan infrastruktur, subsidi, pembayaran pegawai negara, pembangunan fasilitas publik dibiayai dari pajak. 
Sumber penerimaan dalam negeri dapat dibagi menjadi tiga yaitu penerimaan pajak, penerimaan negara bukan pajak (PNBP), dan hibah dalam negeri. Penerimaan pajak berasal dari Pajak Penghasilan (PPh), Pajak Pertambahan Nilai (PPN), Pajak Penjualan atas Barang Mewah (PPnBM), Pajak Bumi dan Bangunan (PBB), Bea Perolehan Hak atas Tanah dan Bangunan (BPHTB), dan penerimaan cukai. Terdapat campur tangan pemerintah dalam penerimaan pajak, diantaranya membuat dan mengeluarkan paket-paket kebijakan baru mengenai pajak.Tujuan dikeluarkannya kebijakan baru ini adalah untuk membantu meningkatkan konstribusi penerimaan pajak.

Pemanfaatan sumber daya alam (SDA), bagian pemerintah atas laba badan usaha milik negara (BUMN), pendapatan pemerintah yang berupa pelayanan kepada masyarakat umum, pendapatan yang berasal dari pengenaan denda administrasi, serta pemasukan lainnya yang telah diatur dalam undang-undang tentang penerimaan negara bukan pajak merupakan pendapatan negara dari PNBP. PNBP memiliki peran penting dalam menopang kebutuhan pendanaan dalam anggaran pendapatan dan belanja negara (APBN), walaupun sangat rentan terhadap perkembangan yang dipengaruhi oleh faktor eksternal.

Penerapan sistem pemungutan pajak dari official assessment system menjadi self assessment system telah diterapkan sejak reformasi perpajakan tahun 1984. Self assessment system adalah sistem pemungutan pajak yang memberikan wewenang kepada wajib pajak untuk menghitung, menyetor, dan melaporkan sendiri jumlah pajak yang seharusnya terutang menurut Undang-Undang. Menurut Riahi (2004) kesadaran yang tinggi dari wajib pajak merupakan faktor penting 
dalam pelaksanaan self assessment system.Pelanggan menilai kinerja aktual suatu penyedia layanan dinilai dari kualitas pelayanan yang digunakan sebagai perbandingan antara harapan yang diinginkan (Cronin, 1992).

Kepatuhan wajib pajak orang pribadi (WPOP) juga dapat dipengaruhi oleh kesadaran serta pemahaman wajib pajak itu sendiri. Berdasarkan penelitian yang dilakukan oleh James dan Alley (2004) kepatuhan pajak adalah subjek yang kompleks dengan implikasi yang luas dan yang memengaruhi kepatuhan tersebut ada dua pendekatan yaitu ekonomi dan perilaku.Menurut Norasmila dan Azlan (2014), kepatuhan pajak yaitu kepatuhan terhadap peraturan dan regulasi pajak, yang mencakup kepatuhan pengisian formulir, pelaporan, dan pembayaran pajak.Tidak adanya peningkatan kepatuhan pajak oleh masyarakat dapat mengancam kegiatan pemerintah yang bertujuan untuk mensejahterakan masyarakat itu sendiri (Chau, 2009).Palil (2005) menemukan bahwa untuk meminimalisir adanya tax aviasion atau penggelapan pajak adalah dengan adanya pemahaman tentang perpajakan yang baik dari wajib pajak itu sendiri.Target yang diinginkanakan tercapai apabila kepatuhan wajib pajak dapat ditingkatkan (Doran, 2009).

Kesadaran wajib pajak sangat diperlukan mengenai fungsi perpajakan yaitu sebagai pembiayaan negara agar kepatuhan wajib pajak dapat ditingkatkan (Jatmiko, 2006).Hasil penelitian oleh Jatmiko (2006) menunjukkan bahwa adanya pengaruh positif antara kesadaran perpajakan terhadap kepatuhan wajib pajak.Hasil serupa juga diperoleh dari penelitian Muliari dan Setiawan (2010) yang menunjukkan bahwa terdapat pengaruh positif yang signifikan antara 
kesadaran wajib pajak terhadap kepatuhan pelaporan wajib pajak orang pribadi yang diteliti pada Kantor Pelayanan Pajak Denpasar Timur.

Pajak sebagai penyumbang terbesar dari penerimaan negara, memiliki pengaruh yang sangat besar terhadap keberlangsungan pembangunan sebuah negara meskipun terdapat sektor - sektor lainnya yang juga berkontribusi pada penerimaan sebuah negara.Terdapat dua fungsi pokok pajak yaitu fungsi anggaran atau budgetair dan fungsi mengatur atau regulerend.Bagi pemerintah pajak dalam aspek anggaran digunakandalam membiayai keperluan pemerintah, dan dalam aspek mengatur atau regulerend adalah sebagai alat untuk mengendalikan dan melangsungkan kebijakan pemerintah dalam bidang sosial dan ekonomi (Mardiasmo, 2016:4).

Undang-Undang telah mengatur ketentuan umum dan tata cara peraturan perpajakan, tak terkecuali mengenai sanksi perpajakan.Harus ada sanksi perpajakan bagi wajib pajak agar wajib pajak mematuhi peraturan perpajakan (Fuadi dan Mangoting, 2013).Wajib pajak berpendapat bahwa apabila sanksi perpajakannya akan lebih banyak merugikannya maka wajib pajak akan memenuhi kewajibannya (Jatmiko, 2006). Ali et al (2001) dalam penelitiannya menyatakan bahwa dengan adanya audit dan sanksi dapat mencegah ketidakpatuhan.

Menurut Parmita Saha et al. (2012), pesatnya perkembanagan penggunaan teknologi informasi dan web diikuti oleh pemerintah yang juga menggunakan teknologi ini dalam memberikan layanan dengan tujuan untuk meningkatkan kualitas layanan dan mencapai efisiensi dalam operasi mereka. Kemajuan 
Luh Putu Santi Krisna dan Ni Ketut Lely Aryani M. Pengaruh...

teknologi yang terus berkembang membuat Direktorat Jendral Pajak berinovasi untuk memberikan kualitas pelayanan agar lebih baik sehingga dapat meningkatkan kepatuhan dan kepuasan wajib pajak dalam membayar pajak.Kemajuan teknologi tersebut dituangkan dalam produk e-Filing atau Electronic Filling Systemyang secara resmi mengacu pada Keputusan Direktur Jenderal Pajak Nomor Kep-88 / PJ / 2004.E-Filing adalah sistem yang dapat menyampaikan Surat Pemberitahuan Tahunan (SPT) atau pemberitahuan perpanjangan SPT yang dilakukan secara elektronik berdasarkan online sistem dengan waktu yang sebenarnya yang dilakukan oleh salah satu perusahaan jasa aplikasi di Indonesia yang diutus oleh Dirjen Pajak.

Berdasarkan pengumuman DJP nomor PENG-04/PJ.09/2016, Pengusaha Kena Pajak (PKP) pengguna e-faktur diwajibkan untuk melakukan e-filing SPT Tahunan Badan.E-filing dapat dilaporkan dengan format CSV file. Terdapat tiga jenis pajak badan yang dapat dilaporkan dengan e-filing pajak online yaitu SPT masa PPh kecuali PPh Pasal 25 yang tidak memiliki CSV file, SPT PPN, dan SPT Tahunan Badan.

E-filing merupakan inovasi perkembangan teknologi informasi dimana Wajib Pajak lebih mudah dalam melaksanakan kewajibannya, serta meningkatkan pelayanan Dirjen Pajak.Terdapat juga layanan pajak online yang siap membantu para pengguna layanan. Pajak online ini dapat diakses kapanpun dan dimanapun, sehingga penyampaian SPT melalui e-filling dapat dilakukan setiap saat atau 24 jam. Wajib pajak yang menganggap bahwa e-filing bermanfaat dan memudahkannya dalam melaksanakan kewajiban perpajakan, akan membuat 
wajib pajak merasa puas menggunakan $e$-filing. Ketika wajib pajak telah merasa puas maka akan memberikan dampak positif terhadap sikap patuh wajib pajak tersebut.

Pemerintah terus melakukan berbagai upaya untuk mendorong pertumbuhan ekonomi.Pemerintah meluncurkan program pengampunan pajak atau tax amnesty untuk menutup defisit APBN. Melalui tax amnesty ini diharapkan dapat mengumpulkan dana tebusan dari kekayaan orang Indonesia yang berada di luar negeri atau aset yang selama ini belum dilaporkan dan dikenai pajak. Dana yang dikumpulkan melalui tax amnesty dapat digunakan untuk memperbaiki kondisi pembangunan, perekonomian, mengurangi kemiskinan, dan memperbaiki ketimpangan.Repatriasi aset wajib pajak yang berada di luar negeri juga dapat menguatkan nilai tukar rupiah.

Pengampunan pajak atau tax amnestymerupakan penghapusan pajak teruntang serta peniadaan denda administrasi maupun denda pidana dalam hal perpajakan.Pengampunan pajak ini dilakukan dengan cara mengungkap harta dan membayar uang tebusan yang telah diatur dalam Undang-Undang No 11 Tahun 2006.Pengampunan pajak ini dilakukan agar wajib pajak yang selama ini tidak melaporkan seluruh harta dan kekayaannya dengan benar memiliki kesempatan memperbaikinya.Tax amnesty adalah salah satu kebijakan pemerintah guna memulangkan kembali dana masyarakat yang tertanam di perbankan negara lain. Pemerintah telah mensosialisasikan Undang-Undang mengenaitax amnesty agar wajib pajak memiliki pemahaman dan pengetahuan yang baik mengenai peraturan tax amnesty. 
Luh Putu Santi Krisna dan Ni Ketut Lely Aryani M. Pengaruh...

- Kepatuhan dalam hal perpajakan merupakan suatu ketaatan untuk melakukan ketentuan-ketentuan atau aturan-aturan perpajakan yang diwajibkan atau diharuskan dilaksanakan menurut peraturan perundang-undangan perpajakan (Ghoni, 2012).Kebijakan pengampunan pajak akan meningkatkan penerimaan pajak dan juga meningkatkan pendapatan nasional, namun realisasi penerimaan pajak tidak sesuai target. Menurut CNN Indonesia, penduduk Indonesia yang berjumlah kurang lebih 250 juta jiwa hanya 27 juta jiwa atau 11 persen yang memiliki Nomor Pokok Wajib Pajak (NPWP). Selama program tax amnesty berlangsung, dirjen pajak telah menjaring ratusan ribu wajib pajak baru yang selama ini tidak tersentuh.Suyanto (2016) menyatakan bahwa tujuan diadakannya program tax amnesty ini adalah adanya peningkatan penerimaan serta perbaikan ekonomi sebuah negara dan peningkatan kesadaran masyarakat atas kewajibannya untuk melakukan pembayaran pajak.

Target kepatuhan pajak nasional yang diharapkan dapat dicapai adalah 72,5 persen berdasarkan Surat Edaran Nomor SE-07 / PJ / 2016 mengenai Penetapan Target dan Strategi Pencapaian Rasio Kepatuhan Wajib Pajak tahun 2016.Data yang diperoleh dari Kantor Pelayanan Pajak (KPP) Pratama Denpasar Timur, menunjukkan bahwa kepatuhan WPOP dari tahun ke tahun mengalami penurunan.Pada tahun 2013 - 2016 tingkat kepatuhan WPOP di KPP Pratama Denpasar Timur disajikan pada Tabel 2 berikut. 
Tabel 2.

Tingkat Kepatuhan Wajib Pajak Orang Pribadi di Kantor Pelayanan Pajak Pratama Denpasar Timur Tahun 2013-2016

\begin{tabular}{cccccc}
\hline No & Tahun & $\begin{array}{c}\text { WPOP } \\
\text { terdaftar }\end{array}$ & $\begin{array}{c}\text { WPOP } \\
\text { efektif }\end{array}$ & $\begin{array}{c}\text { WPOP yang } \\
\text { menyampaikan } \\
\text { SPT }\end{array}$ & $\begin{array}{c}\text { Kepatuhan pajak } \\
(\%)\end{array}$ \\
\hline 1 & 2013 & 82.648 & 60.195 & 35.186 & $58,45 \%$ \\
2 & 2014 & 87.034 & 64.576 & 35.356 & $54,75 \%$ \\
3 & 2015 & 91.739 & 69.280 & 37.419 & $54,01 \%$ \\
4 & 2016 & 95.775 & 73.316 & 38.783 & $52,91 \%$ \\
\hline
\end{tabular}

Sumber: KPP Pratama Denpasar Timur, 2017

Berdasarkan Tabel 2, dapat dilihat bahwa tingkat kepatuhan wajib pajak orang pribadi di KPP Pratama Denpasar Timur dari tahun 2013-2015 mengalami penurunan. Persentase kepatuhan tahun 2013 sebesar 58,45\%, serta turun menjadi 54,75\% pada tahun 2014, tahun 2015 turun menjadi 54,01\%, lalu di tahun 2016 juga mengalami penurunan menjadi $52,91 \%$. Salah satu faktor penurunan kepatuhan wajib pajak adalah kurangnya kesadaran dari wajib pajak itu sendiri serta penegakan hukum pajak di Indonesia tidak sekuat penegakan hukum di negara maju.

Berdasarkan uraian di atas, maka rumusan masalah yang diangkat adalah 1) Apakah pengaruh kesadaran wajib pajak terhadap kepatuhan pelaporan wajib pajak orang pribadi di Kantor Pelayanan Pajak Pratama Denpasar Timur? 2) Apakah pengaruh sanksi perpajakan terhadap kepatuhan pelaporan wajib pajak orang pribadi di Kantor Pelayanan Pajak Pratama Denpasar Timur? 3) Apakah pengaruh sistem $e$-filing terhadap kepatuhan pelaporan wajib pajak orang pribadi di Kantor Pelayanan Pajak Pratama Denpasar Timur? 4) Apakah pengaruh pengetahuan tax amnesty terhadap kepatuhan pelaporan wajib pajak orang pribadi di Kantor Pelayanan Pajak Pratama Denpasar Timur? 
Adapun tujuan penelitian ini adalah: 1) Untuk menganalisis pengaruh kesadaran wajib pajak terhadap kepatuhan pelaporan WPOP di Kantor Pelayanan Pajak Pratama Denpasar Timur; 2) Untuk menganalisis pengaruh sanksi perpajakan terhadap kepatuhan pelaporan WPOP di Kantor Pelayanan Pajak Pratama Denpasar Timur; 3) Untuk menganalisis pengaruh sistem e-filing terhadap kepatuhan pelaporan WPOP di Kantor Pelayanan Pajak Pratama Denpasar Timur; 4) Untuk menganalisis pengaruh pengetahuan tax amnesty terhadap kepatuhan pelaporan WPOP di Kantor Pelayanan Pajak Pratama Denpasar Timur.

Manfaat dari penelitian ini ada dua yaitu manfaat teoritis dan manfaat praktis. Secara teoritis hasil penelitian ini nantinya dapat berfungsi untuk menambah pengetahuan dalam bidang perpajakan mengenai kepatuhan wajib pajak orang pribadiserta dapat memberikan bukti empiris atas theory of planned behavior dan teori pengambilan keputusan. Selain itu, hasil penelitian ini sangat diharapkan untuk dapat digunakan oleh peneliti selanjutnya sebagai referensi. Secara praktis hasil penelitian ini nantinya dapat menjadi tambahan informasi, masukan, sumbangan pemikiran, dan bahan pertimbangan mengenai kesadaran wajib pajak, sanksi perpajakan, penerapan sistem e-filing, dan pengetahuan tax amnesty agar dapat menjadi bahan dasar evaluasi di masa datang oleh pihak pembuat kebijakan perpajakan.

Penelitian sebelumnya yang menggunakan teori ini dilakukan oleh Mustikasari (2007).Berdasarkantheory of planned behavior dan teori pengambilan keputusan,theory of planned behavior menyatakan bahwa niat berperilaku oleh 
seorang individu dapat dipengaruh oleh perilaku. Teori tersebut dapat digunakan untuk memperjelas perilaku yang dilakukan wajib pajak secara relevan untuk memenuhi kewajiban pembayaran pajaknya.Mengacu pada TPB, Ajzen (1991) mengutarakan bahwa faktor utama yang mempengaruhi perilaku seorang individu yaitu niat dari individu tersebut dalam berperilaku.Biasanya sebelum seorang individu melakukan sesuatu, individu tersebut berkeyakinan atas hasil dari sesuatu yang dilakukannya tersebut.

Menurut Curtis R. Finch dan Robert L. McGough (1982) pengambilan keputusan adalah tindakan dari sejumlah alternatif yang ada.Penelitian ini menggunakan teori pengambilan keputusan karena untuk mengetahui pengetahuan wajib pajak terkait manfaat yang diperoleh dari program tax amnesty. Dengan adanya pemahaman yang baik oleh wajib pajak mengenai tax amnesty, diharapkan dapat meningkatkan kepatuhan wajib pajak dengan memutuskan akan mengikuti program tax amnesty atau tidak.

Penelitian yang dilakukan oleh Dewinta dan Syafruddin (2012), semakin tinggi tingkat kesadaran wajib pajak maka pemahaman dan pelaksanaan kewajiban perpajakan semakin baik sehingga dapat meningkatkan kepatuhan.Penelitian yang dilakukan oleh Astana dan Lely (2017) juga menunjukkan bahwa adanya pengaruh positif antara kesadaran wajib pajak terhadap kepatuhan WPOP.Adapun rumusan hipotesis dalam penelitian ini adalah sebagai berikut.

$\mathrm{H}_{1}$ : Kesadaran wajib pajak berpengaruh positif terhadap kepatuhan pelaporan wajib pajak orang pribadi. 
Luh Putu Santi Krisna dan Ni Ketut Lely Aryani M. Pengaruh...

Pemberian saksi yang tegas merupakan salah satu alternatif yang dapat dilakukan untuk mengatasi tidak patuhnya wajib pajak akan pemenuhan kewajiban pembayaran pajaknya serta mendorong motivasi wajib pajak untuk meningkatkan efektivitas sistem perpajakan (Webley et.al, 1991).Faisal (2009) menjelaskan bahwa tujuan utama pemberian saksi bukanlah dalam hal peningkatan penerimaan negara melainkan untuk meningkatkan kesadaran masyarakat untuk memenuhi kewajibannya dalam bidan pajak.Muliari dan Setiawan (2011) menyatakan bahwa sanksi perpajakan berpengaruh terhadap kepatuhan pelaporan wajib pajak.Arum (2012) menyatakan bahwa terdapat pengaruh positif antara sanksi perpajakan terhadap kepatuhan pelaporan wajib pajak.Adapun rumusan hipotesis dalam penelitian ini adalah sebagai berikut.

$\mathrm{H}_{2}$ : Sanksi perpajakan berpengaruh positif terhadap kepatuhan pelaporan wajib pajak orang pribadi.

Salah satu upaya yang dapat dilakukan untuk mempermudah wajib pajak dalam pemenuhan kewajiban pajaknya adalah dengan melakukan reformasi administrasi perpajakan (Punarbhawa dan Lely, 2013).Menurut Desmayanti (2012) bahwa kesiapan teknologi informasi wajib pajak berpengaruh signifikan positif terhadap intensitas perilaku dalam penggunaan $e$-filing.Kemudahan yang dirasakan oleh wajib pajak dalam penggunaan e-filing inilah yang akan membentuk sikap positif dan membuat wajib pajak semakin patuh karna pengisian dan pelaporan e-filing ini dapat dilakukan dengan cara online dan real time. Semakin mudah penerapan sistem e-filing, semakin patuh pula wajib pajak tersebut.Berdasarkan hal tersebut maka dirumuskan hipotesis sebagai berikut. 
$\mathrm{H}_{3}$ : Penerapan sistem $e$-filing berpengaruh positif terhadap kepatuhan pelaporan wajib pajak orang pribadi.

Menurut penelitian Jacques (2010) menunjukkan bahwa tax amnesty berpengaruh postif terhadap tingkat kepatuhan wajib pajak. Penelitian oleh Junpath (2013) berkenaan dengan tax amnesty dan kepatuhan pajak yang dilakukan di Afrika Selatan, menunjukkan hasil bahwa terdapat pengaruh positif antara tax amnestyterhadap penerimaan pajak dan kepatuhan perpajakan di Afrika Selatan. Adapun rumusan hipotesis dalam penelitian ini adalah sebagai berikut.

$\mathrm{H}_{4}$ : Pengetahuan tax amnesty berpengaruh positif terhadap kepatuhan pelaporan wajib pajak orang pribadi.

\section{METODE PENELITIAN}

Penelitian ini dilakukan dengan pendekatan kuantitatif yang tingkat eksplansi penelitiannya berbentuk asosiatif.Penelitian asosiatif adalah bentuk penelitian dengan tujuan untuk mengetahui hubungan antara dua variabel atau lebih.Lokasi penelitian yang dipilih adalah di Kantor Pelayanan Pajak (KPP) Pratama Denpasar Timur, yang terletak di Jalan Tantular No. 4, Renon, Denpasar Timur, Kota Denpasar, Bali.Pemilihan lokasi penelitian ini karena terjadinya penurunan tingkat kepatuhan wajib pajak orang pribadi dari tahun 2013 sampai tahun 2016.

Jenis data yang digunakan dalam penelitian ini adalah sebagai berikut. 1) Data kualitatif, yang digunakan untuk memperoleh informasi mengenaisejarah singkat, gambaran umum, dan struktur organisasi di KPP Pratama Denpasar Timur; 2) Data kuantitatif, yaitu data mengenai wajib pajak orang pribadi misalnyadata jumlah efektif, jumlah yang menyampaikan SPT, data mengenai jumlah terdaftar, serta jawaban responden yang dikuantitatifkan berdasarkan 
Luh Putu Santi Krisna dan Ni Ketut Lely Aryani M. Pengaruh...

pernyataan atau pertanyaan pada kuesioner dengan menggunakan skala likert.Data penelitian ini bersumber dari data primer dan data sekunder. 1) Data primer, diperoleh darijawaban responden atas kuesioner mengenai kesadaran wajib pajak, penerapan sistem e-filing,sanksi perpajakan, kepatuhan pelaporan wajib pajak orang pribadi dan pemahaman tax amnesty; 2) Data sekunder berupa data yang diperoleh dari KPP Pratama Denpasar Timur.

Populasi yang diteliti adalah keseluruhanWPOP yang terdaftar dan merupakan wajib pajak efektif di KPP Pratama Denpasar Timur yaitu sebanyak 73.316 WPOP.Jumlah sampel ditentukan dengan menggunakan rumus Slovin, yaitu didapat 100 sampel, dengan batas kesalahan 10\%.Sampel dalam penelitian ini menggunakan metode nonprobability sampling dengan teknik purposive sampling.Purposive sampling adalah metode penentuan sampel dengan pertimbangan tertentu, dimana anggota sampel yang dipilih dapat mewakili sifatsifat populasi.Kriteria pemilihan sampel yang digunakan adalah sebagai berikut. 1) WPOP yang terdaftar serta termasuk wajib pajak efektif di KPP Pratama Denpasar Timur; 2) WPOP yang menggunakan sistem e-filing; 3) WPOP yang mengetahui dan mengerti mengenai tax amnesty.

Pengumpulan data dalam penelitian ini dilakukan adalah sebagai berikut. 1) Kuesioner yang diberikan secara langsung kepada responden yang berada di lokasi penelitian, dan diukur dengan skala likert 4. Nilai dari skala likert yaitu, skor 1 = sangat tidak setuju (STS), 2 = tidak setuju (TS), 3 = setuju (S), dan $4=$ sangat setuju (SS); 2) Observasi non partisipan, dimana peneliti mengamati, mencatat, mengutip, dan mengumpulkan data yang berkaitan dengan penelitian. 
Teknik analisis data yang digunakan dalam penelitian ini adalah uji validitas, uji reliabilitas, uji normalitas, uji multikolinearitas, uji heteroskedasitas, analisis statistik deskriptif, analisis regresi linier berganda, koefisien determinasi $\left(\mathrm{R}^{2}\right)$, uji kelayakan model (uji f), dan uji hipotesis (uji t).

\section{HASIL DAN PEMBAHASAN}

Kuesioner dalam penelitian ini disebarkan kepada 100 responden yang telah memenuhi kriteria sebagai sampel. Kuesioner yang disebar sebanyak 142 kuesioner, dimana hanya 100 yang dijadikan sampel karena sebanyak 25 kuesioner tidak kembali, 10 kuesioner tidak lengkap, dan 7 kuesioner tidak memenuhi kriteria. Terdapat 55 responden laki-laki, dan 45 responden perempuan.Jenis kelamin responden digunakan sebagai acuan untuk mengetahui proporsi WPOP dalam kepatuhannya untuk membayar pajak. Berdasarkan umur, responden yang berusia antara 21-30 tahun adalah 10 orang, yang berusia 31-40 tahun adalah 17 orang, yang berusia 41-50 tahun adalah 39 orang, yang berusia 51-60 tahun adalah 33 orang, dan yang berusia 66 tahun adalah 1 orang. Umur responden dapat menggambarkan kedewasaan dan pengalaman seseorang, dimana WPOP memiliki pengetahuan yang memadai mengenai perpajakannya karena responden dalam penelitian ini didominasi oleh WPOP yang berumur 41 sampai 60 tahun. Jenis pekerjaan responden digunakan sebagai indikator untuk mengetahui proporsi pekerjaan WPOP. Jenis pekerjaan responden yang bekerja sebagai PNS adalah 65 orang, yang bekerja pegawai swasta adalah 16 orang, dan yang bekerja pada bidang lainnya adalah 19 orang. Seluruh responden dalam 
penelitian ini adalah WPOP yang terdaftar di KPP Pratama Denpasar Timur dan pernah menggunakan $e$-filing.

Uji validitas digunakan untuk mengukur sejauh mana ketepatan alat ukur penelitian tentang isi atau arti sebenarnya yang diukur. Apabila korelasi tiap faktor bernilai positif dan lebih dari 0,30 menunjukkan bahwa butir pernyataan yang digunakan pada penelitian ini terbukti valid (Ghozali, 2016:55).Berikut hasil uji validitas dapat dilihat pada Tabel 3.

Tabel 3. Hasil Uji Validitas

\begin{tabular}{lccc}
\hline \multicolumn{1}{c}{ Variabel Penelitian } & Indikator & $\begin{array}{c}\text { Pearson } \\
\text { Correlation }\end{array}$ & Keterangan \\
\hline Kesadaran wajib pajak & $\mathrm{X}_{1.1}-\mathrm{X}_{1.4}$ & $0,656-0,836$ & Valid \\
Sanksi perpajakan & $\mathrm{X}_{2.1}-\mathrm{X}_{2.6}$ & $0,569-0,802$ & Valid \\
Penerapan sistem e-filing & $\mathrm{X}_{3.1}-\mathrm{X}_{3.8}$ & $0,648-0,834$ & Valid \\
Pengetahuan tax amnesty & $\mathrm{X}_{4.1}-\mathrm{X}_{4.5}$ & $0,719-0,824$ & Valid \\
Kepatuhan pelaporan WPOP & $\mathrm{Y}_{1}-\mathrm{Y}_{7}$ & $0,608-0,751$ & Valid \\
\hline Sumber: Data Diolah, 2017 & & &
\end{tabular}

Berdasarkan Tabel 3 dapat dilihat bahwa nilai Pearson Correlation dari masing-masing pernyataan adalah positif dan lebih dari 0,30. Hal ini menunjukkan bahwa pernyataan dalam kuesioner adalah valid.

Instrumen yang reliabel adalah instrumen yang digunakan beberapa kali untuk mengukur objek yang sama akan menghasilkan data atau jawaban yang sama pula. Pengujian reliabilitas dapat dilakukan dengan uji statistic Cronbach Alpha.Suatu instrument dikatakan reliabel jika memberikan nilai Cronbach Alpha lebih besar dari 0,70 (Ghozali, 2016:48).Berikut hasil uji reliabilitas dapat dilihat pada Tabel 4. 
Tabel 4.

Hasil Uji Reliabilitas

\begin{tabular}{lcc}
\hline \multicolumn{1}{c}{ Variabel Penelitian } & Croncabh's alpha & keterangan \\
\hline Kesadaran wajib pajak $\left(\mathrm{X}_{1}\right)$ & 0,749 & Reliabel \\
Sanksi perpajakan $\left(\mathrm{X}_{2}\right)$ & 0,781 & Reliabel \\
Penerapan sistem e-filing $\left(\mathrm{X}_{3}\right)$ & 0,876 & Reliabel \\
Pengetahuan tax amnesty $\left(\mathrm{X}_{4}\right)$ & 0,836 & Reliabel \\
Kepatuhan pelaporan WPOP $(\mathrm{Y})$ & 0,801 & Reliabel \\
\hline Sumber:
\end{tabular}

Sumber: Data Diolah, 2017

Berdasarkan Tabel 4 dapat dilihat bahwa seluruh variabel penelitian memiliki nilai Cronbach Alpha lebih besar dari 0,70. Hal tersebut menunjukkan bahwa seluruh variabel penelitian adalah reliabel dan pernyataan dalam kuesioner layak digunakan sebagai alat ukur.

Uji normalitas bertujuan untuk menguji apakah dalam model regresi, variabel pengganggu atau residual memiliki distribusi normal. Pengujian ini menggunakan model One Sample Kolmogrov-Smirnov Test dengan bantuan program SPSS. Distribusi data dikatakan normal apabila nilai dari probability asymp.sig (2-tailed) > 0,05 atau lebih besar dari 0,05.Berikut hasil uji normalitas dapat dilihat pada Tabel 5.

Tabel 5.

Hasil Uji Normalitas

\begin{tabular}{lc}
\hline \multicolumn{1}{c}{ Keterangan } & Unstandardized Residual \\
\hline $\mathrm{N}$ & 100 \\
\hline asymp.sig (2-tailed) & 0,200 \\
\hline Sumber: Data Diolah, 2017 &
\end{tabular}

Berdasarkan Tabel 5 dapat dilihat bahwa nilai asymp.sig (2-tailed) sebesar 0,200 yaitu lebih besar dari 0,05 . Hal ini berarti model regresi dalam penelitian ini berdistribusi normal. 
Luh Putu Santi Krisna dan Ni Ketut Lely Aryani M. Pengaruh...

Uji multikolinearitas bertujuan untuk menguji apakah dalam model regresi ditemukan adanya korelasi antar variabel bebas.Model regresi yang baik seharusnya tidak terjadi korelasi diantara variabel bebas.Untuk mendeteksi ada atau tidaknya multikolinearitas di dalam regresi dapat dilihat dari nilai tolerance dan Variance Inflasing Factor (VIF). Jika nilai tolerance > 0,10 atau nilai VIF < 10, maka model dikatakan bebas dari gejala multikolonieritas (Ghozali, 2016:104). Berikut hasil uji multikolinearitas dapat dilihat pada Tabel 6.

Tabel 6.

Hasil Uji Multikolinearitas

\begin{tabular}{lccl}
\hline \multicolumn{1}{c}{ Variabel } & Tolerance & VIF & Keterangan \\
\hline Kesadaran wajib pajak $\left(\mathrm{X}_{1}\right)$ & 0,629 & 1.59 & Bebas Multikolinearitas \\
Sanksi perpajakan $\left(\mathrm{X}_{2}\right)$ & 0,586 & 1.707 & Bebas Multikolinearitas \\
Penerapan sistem e-filing $\left(\mathrm{X}_{3}\right)$ & 0,577 & 1.734 & Bebas Multikolinearitas \\
Pengetahuan tax amnesty $\left(\mathrm{X}_{4}\right)$ & 0,597 & 1.675 & Bebas Multikolinearitas \\
\hline
\end{tabular}

Sumber: Data Diolah, 2017

Berdasarkan Tabel 6 dapat dilihat bahwa nilai tolerance lebih besar dari 0,10 dan nilai VIF dibawah 10.Dapat disimpulkan bahwa tidak terdapat korelasi pada masing-masing variabel bebas atau bebas multikolinearitas.

Uji heteroskedesitas bertujuan untuk menguji apakah dalam model regresi terjadi ketidaksamaan varian dari residual satu pengamatan ke pengamatan yang lain. Cara untuk mendeteksi ada atau tidaknya heteroskedastisitas dalam penelitian ini adalah dengan menggunakan uji Glejser.Tingkat probabilitas signifikansi masing-masing variabel bebas jika lebih besar dari 0,05 maka dapat disimpulkan bahwa tidak terdapat heteroskedasitas (Ghozali, 2016:138).Berikut hasil uji heterokedesitas dapat dilihat pada Tabel 7. 
Tabel 7.

Hasil Uji Heteroskedesitas

\begin{tabular}{lcl}
\hline \multicolumn{1}{c}{ Variabel } & Sig & Keterangan \\
\hline Kesadaran wajib pajak $\left(\mathrm{X}_{1}\right)$ & 0,945 & Bebas heteroskedesitas \\
\hline Sanksi perpajakan $\left(\mathrm{X}_{2}\right)$ & 0,058 & Bebas heteroskedesitas \\
\hline Penerapan sistem -filing $\left(\mathrm{X}_{3}\right)$ & 0,053 & Bebas heteroskedesitas \\
\hline Pengetahuan tax amnesty $\left(\mathrm{X}_{4}\right)$ & 0,086 & Bebas heteroskedesitas \\
\hline Sumber: Data Diolah, 2017 & &
\end{tabular}

Berdasarkan Tabel 7 dapat dilihat nilai signifikansi setiap variabel bebas berada di atas 0,05. Hal ini berarti tidak ada satupun variabel bebas yang berpengaruh signifikan terhadap variabel terikat, sehingga model regresi penelitian ini bebas dari gejala heteroskedesitas.

Analisis statistik deskriptif adalah pengujian statistik yang digunakan untuk menganalisis data dengan memberikan gambaran atau deskripsi terhadap suatu data mengenai nilai rata-rata (mean), standar deviasi, maksimum dan minimum.Berikut hasil uji statistik deskriptif dapat dilihat pada Tabel 8.

Tabel 8.

Hasil Uji Statistik Deskriptif

\begin{tabular}{|c|c|c|c|c|c|}
\hline Variabel & $\mathbf{N}$ & Minimal & Maximum & Mean & $\begin{array}{c}\text { Std. } \\
\text { deviation }\end{array}$ \\
\hline $\begin{array}{l}\text { Kesadaran wajib } \\
\text { pajak }\left(\mathrm{X}_{1}\right)\end{array}$ & 100 & 7,00 & 16,00 & 12,70 & 2,003 \\
\hline $\begin{array}{l}\text { Sanksi perpajakan } \\
\left(\mathrm{X}_{2}\right)\end{array}$ & 100 & 13,00 & 24,00 & 19,56 & 2,687 \\
\hline $\begin{array}{l}\text { Penerapan sistem e- } \\
\text { filing }\left(\mathrm{X}_{3}\right)\end{array}$ & 100 & 12,00 & 32,00 & 25,97 & 3,436 \\
\hline $\begin{array}{l}\text { Pengetahuan tax } \\
\text { amnesty }\left(\mathrm{X}_{4}\right)\end{array}$ & 100 & 6,00 & 20,00 & 15,34 & 2,779 \\
\hline $\begin{array}{l}\text { Kepatuhan } \\
\text { pelaporan WPOP } \\
(\mathrm{Y})\end{array}$ & 100 & 14,00 & 28,00 & 22,54 & 2,721 \\
\hline
\end{tabular}

Rata-rata (Mean) digunakan untuk mengukur nilai sentral dari suatu distribusi data dan standar deviasi digunakan untuk mengukur perbedaan nilai 
data yang diteliti dengan nilai rata-ratanya.Tabel 8 menunjukkan hasil statistik deskriptif sebagai berikut. 1) Variabel kesadaran wajib pajak memiliki nilai minimum 7 dan nilai maksimum 16, dengan nilai rata-rata sebesar 12,70 . Nilai rata-rata sebesar 12,70 dimana nilai tersebut mendekati nilai maksimal yang artinya kesadaran yang dimiliki WPOP cukup tinggi; 2) Variabel sanksi perpajakan memiliki nilai minimum 13 dan nilai maksimum 24, dengan nilai ratarata sebesar 24,00 . Nilai rata-rata sebesar 24,00 dimana nilai tersebut mendekati nilai maksimal yang artinya sanksi perpajakan yang diterima WPOP cukup tinggi; 3) Variabel penerapan sistem e-filing memiliki nilai minimum 12 dan nilai maksimum 32, dengan nilai rata-rata sebesar 25,97. Nilai rata-rata sebesar 25,97 dimana nilai tersebut mendekati nilai maksimal yang artinya penggunaan $e$-filing oleh WPOP cukup tinggi; 4) Variabel pengetahuan tax amnesty memiliki nilai minimum 6 dan nilai maksimum 20, dengan nilai rata-rata sebesar 15,34. Nilai rata-rata sebesar 15,34 dimana nilai tersebut mendekati nilai maksimal yang artinya pengetahuan WPOP mengenai tax amnesty cukup tinggi; 5) Variabel kepatuhan pelaporan WPOP memiliki nilai minimum 14 dan nilai maksimum 28, dengan nilai rata-rata sebesar 22,54. Nilai rata-rata sebesar 22,54 dimana nilai tersebut mendekati nilai maksimal yang artinya kepatuhan pelaporan yang dimiliki oleh WPOP cukup tinggi.

Analisis regresi linier berganda digunakan untuk menguji pengaruh variabel kesadaran wajib pajak, sanksi perpajakan, penerapan sistem e-filing, dan pengetahuan tax amnesty terhadap kepatuhan pelaporan WPOP.Hasil analisis regresi linier berganda dapat dilihat pada Tabel 9 berikut. 
Tabel 9.

Hasil Analisis Regresi Linier Berganda

\begin{tabular}{|c|c|c|c|c|c|}
\hline \multirow[t]{2}{*}{ Variabel } & \multicolumn{2}{|c|}{$\begin{array}{c}\text { Unstandardized } \\
\text { Coeficient }\end{array}$} & \multirow{2}{*}{$\begin{array}{c}\begin{array}{c}\text { Standardized } \\
\text { Coeficient }\end{array} \\
\text { Beta }\end{array}$} & \multirow[t]{2}{*}{$\mathbf{t}$} & \multirow[t]{2}{*}{ Signifikansi } \\
\hline & B & Std. Eror & & & \\
\hline Constant & 7,108 & 1,737 & & 4,093 & 0,000 \\
\hline $\begin{array}{l}\text { Kesadaran wajib } \\
\text { pajak }\left(\mathrm{X}_{1}\right)\end{array}$ & 0,287 & 0,124 & 0,211 & 2,310 & 0,023 \\
\hline $\begin{array}{l}\text { Sanksi } \\
\text { perpajakan }\left(X_{2}\right)\end{array}$ & 0,107 & 0,096 & 0,106 & 1,116 & 0,047 \\
\hline $\begin{array}{l}\text { Penerapan sistem } \\
\text { e-filing }\left(\mathrm{X}_{3}\right)\end{array}$ & 0,172 & 0,076 & 0,218 & 2,280 & 0,025 \\
\hline $\begin{array}{l}\text { Pengetahuan tax } \\
\text { amnesty }\left(\mathrm{X}_{4}\right)\end{array}$ & 0,340 & 0,092 & 0,347 & 3,694 & 0,00 \\
\hline $\begin{array}{l}\text { Adjusted R } \\
\text { Square }\end{array}$ & & & 0,479 & & \\
\hline F hitung & & & 23,737 & & \\
\hline Signifikansi F & & & 0,000 & & \\
\hline
\end{tabular}

Sumber: Data Diolah, 2017

Berdasarkan Tabel 9 dapat disusun persamaan regresi sebagai berikut.

$$
Y=7,108+0,287 X_{1}+0,107 X_{2}+0,172 X_{3}+0,340 X_{4}+\varepsilon
$$

Berdasarkan persamaan regresi diatas, dapat dijelaskan hal-hal sebagai berikut. 1) Nilai konstanta ( $\beta$ ) sebesar 7,108 memiliki arti bahwa variabel kesadaran wajib pajak, sanksi perpajakan, penerapan sistem e-filing, dan pengetahuan tax amnesty berpengaruh positif pada variabel kepatuhan pelaporan WPOP, apabila variabel kesadaran wajib pajak, sanksi perpajakan, penerapan sistem e-filing, dan pengetahuan tax amnesty konstan, maka nilai variabel kepatuhan pelaporan WPOP cenderung naik 7,108 satuan; 2) Nilai koefisien $\beta_{1}$ sebesar 0,287 memiliki arti bahwa apabila nilai kesadaran wajib pajak $\left(\mathrm{X}_{1}\right)$ meningkat satu kesatuan, maka kepatuhan pelaporan wajib pajak orang pribadi akan mengalami peningkatan sebesar 0,287 satuan dengan asumsi variabel bebas lainnya konstan; 3) Nilai koefisien $\beta_{2}$ sebesar 0,107 memiliki arti bahwa apabila 
Luh Putu Santi Krisna dan Ni Ketut Lely Aryani M. Pengaruh...

nilai sanksi perpajakan $\left(\mathrm{X}_{2}\right)$ meningkat satu kesatuan, maka kepatuhan pelaporan wajib pajak orang pribadi akan mengalami peningkatan sebesar 0,107 satuan dengan asumsi variabel bebas lainnya konstan; 4)Nilai koefisien $\beta_{3}$ sebesar 0,172 memiliki arti bahwa apabila nilai penerapan sistem e-filing $\left(\mathrm{X}_{3}\right)$ meningkat satu kesatuan, maka kepatuhan pelaporan wajib pajak orang pribadi akan mengalami peningkatan sebesar 0,172 kesatuan dengan asumsi variabel bebas lainnya konstan; 5) Nilai koefisien $\beta_{4}$ sebesar 0,340 memiliki arti bahwa apabila nilai pengetahuan tax amnesty $\left(\mathrm{X}_{4}\right)$ meningkat satu kesatuan, maka kepatuhan pelaporan wajib pajak orang pribadi akan mengalami peningkatan sebesar 0,340 kesatuan dengan asumsi variabel bebas lainnya konstan.

Koefisien determinasi digunakan untuk mengukur seberapa jauh kemampuan model dalam menerangkan variasi variabel dependen. Besarnya nilai koefisien determinasi $\left(\mathrm{R}^{2)}\right.$ ditunjukkan dengan nilai adjusted $R$ square. Hasil koefisien determinasi $\left(\mathrm{R}^{2}\right)$ dapat dilihat pada Tabel 10 berikut.

Tabel 10.

Hasil Analisis Koefisien Determinasi $\left(\mathbf{R}^{2}\right)$

\begin{tabular}{ccccc}
\hline Model & R & R Square & Adjusted R Square & $\begin{array}{c}\text { Std. Error of the } \\
\text { Estimate }\end{array}$ \\
\hline 1 & 0,707 & 0,500 & 0,479 & 1,964 \\
\hline
\end{tabular}

Sumber: Data Diolah, 2017

Berdasarkan Tabel 10 nilai adjusted $R$ square sebesar 0,479. Hasil ini menunjukkan bahwa 47,9 persen kepatuhan pelaporan wajib pajak orang pribadi dipengaruhi oleh variabel kesadaran wajib pajak, sanksi perpajakan, penerapan sistem e-filing, dan pengetahuan tax amnesty, sedangkan 52,1 persen dijelaskan oleh variabel lain diluar model. 
Uji kelayakan model (uji f) dilakukan untuk mengetahui kelayakan model penelitian yang digunakan sebagai alat analisis untuk menguji pengaruh variabel independen terhadap variabel dependen.Apabila nilai signifikansi lebih kecil dari 0,05 maka variabel independen layak digunakan sebagai alat analisis.Hasil uji kelayakan model (uji F) dapat dilihat pada Tabel 11 berikut.

Tabel 11.

Uji Kelayakan Model (Uji F)

\begin{tabular}{lccccc}
\hline \multicolumn{1}{c}{ Model } & Sum of squares & df & Mean square & F & sig. \\
\hline Regression & 366,322 & 4 & 91,581 & 23,737 & 0,000 \\
\hline Residual & 366,518 & 95 & 3,858 & & \\
\hline Total & 732,840 & 99 & & & \\
\hline
\end{tabular}

Sumber: Data Diolah, 2017

Berdasarkan Tabel 11 hasil uji $\mathrm{F}$ menunjukkan nilai $\mathrm{F}$ hitung sebesar 23,737 dengan nilai $p$-value sebesar 0,000. Dapat disimpulkan bahwa kesadaran wajib pajak, sanksi perpajakan, penerapan sistem e-filing, dan pengetahuan tax amnesty layak digunakan untuk memprediksi kepatuhan pelaporan wajib pajak orang pribadi, sehingga pembuktian hipotesis dapat dilakukan.

Hasil uji t, level of significant $(\alpha)$ yang digunakan adalah 0,05.Apabila tingkat signifikansi t hitung lebih kecil dari pada 0,05 maka dapat dikatakan variabel bebas tersebut secara individual memengaruhi variabel terikat atau hipotesis diterima.Hasil uji t dapat dilihat pada Tabel 12.

Tabel 12.

Uji Hipotesis (Uji t)

\begin{tabular}{lccc}
\hline \multicolumn{1}{c}{ Variabel } & $\mathbf{t}_{\text {hitung }}$ & sig. & $\mathbf{t}_{\text {tabel }}$ \\
\hline Kesadaran wajib pajak $\left(\mathrm{X}_{1}\right)$ & 2,310 & 0,023 & 1,985 \\
Sanksi perpajakan $\left(\mathrm{X}_{2}\right)$ & 1,116 & 0,047 & 1,985 \\
Penerapan sistem e-filing $\left(\mathrm{X}_{3}\right)$ & 2,280 & 0,025 & 1,985 \\
Pengetahuan tax amnesty $\left(\mathrm{X}_{4}\right)$ & 3,694 & 0,000 & 1,985 \\
\hline Sumber: Data Diola 2017 &
\end{tabular}


Luh Putu Santi Krisna dan Ni Ketut Lely Aryani M. Pengaruh...

Berdasarkan Tabel 12 dapat dilihat hasil dari pengujian parsial masingmasing variabel bebas pada variabel terikat, yang dijabarkan sebagai berikut. 1) Hipotesis pertama yaitu kesadaran wajib pajak berpengaruh positif terhadap kepatuhan pelaporan wajib pajak orang pribadi. Berdasarkan Tabel 4.12 nilai t hitung kesadaran wajib pajak adalah sebesar 2,310 dan nilai p-value adalah sebesar 0,023 . Artinya hipotesis diterima karena $0,023<0,05$. Ini membuktikan bahwa kesadaran wajib pajak berpengaruh positif terhadap kepatuhan pelaporan wajib pajak orang pribadi; 2) Hipotesis kedua yaitu sanksi perpajakan berpengaruh positif terhadap kepatuhan pelaporan wajib pajak orang pribadi.Berdasarkan Tabel 4.12 nilai t hitung sanksi perpajakan adalah sebesar 1,116 dan nilai $p$-value 0,047 . Artinya hipotesis diterima karena nilai t hitung adalah postif dan nilai $p$-value adalah $0,047<0,05$. Ini membuktikan bahwa sanksi perpajakan berpengaruh positif terhadap kepatuhan pelaporan wajib pajak orang pribadi; 3) Hipotesis ketiga yaitu penerapan sistem e-filing berpengaruh positif terhadap kepatuhan pelaporan wajib pajak orang pribadi.Berdasarkan Tabel 4.12 nilai t hitung penerapan sistem $e$-filing adalah sebesar 2,280 dan nilai p-value adalah sebesar 0,025. Artinya hipotesis diterima karena nilai t hitung adalah positif dan nilai $p$-value adalah $0,025<0,05$. Ini membuktikan bahwa penerapan sistem $e$-filing berpengaruh positif terhadap kepatuhan pelaporan wajib pajak orang pribadi; 4) Hipotesis keempat yaitu pengetahuan tax amnesty berpengaruh positif terhadap kepatuhan pelaporan wajib pajak orang pribadi.Berdasarkan Tabel 4.12 nilai t hitung pengetahuan tax amnesty adalah sebesar 3,694 dan nilai p-value adalah sebesar 0,000. Artinya hipotesis diterima 
karena nilai t hitung adalah positif dan nilai $p$-value adalah $0,000<0,05$. Ini membuktikan bahwa pengetahuan tax amnesty berpengaruh positif terhadap kepatuhan pelaporan wajib pajak orang pribadi.

Hasil pengujian hipotesis pertama menunjukkan bahwa variabel kesadaran wajib pajak berpengaruh positif terhadap kepatuhan pelaporan wajib pajak orang pribadi. Nilai t hitung variabel kesadaran wajib pajak adalah sebesar 2,310 dan nilai $p$-value sebesar $0,023<0,05$ yang artinya berpengaruh positif. Hal ini menunjukkan bahwa hipotesis diterima.Hasil uji ini konsisten dengan penelitian yang dilakukan oleh Dewinta dan Syafruddin (2012).Kesadaran wajib pajak berpengaruh positif terhadap kepatuhan wajib pajak.Semakin tinggi tingkat kesadaran wajib pajak maka pemahaman dan pelaksanaan kewajiban perpajakan semakin baik sehingga dapat meningkatkan kepatuhan.

Hasil pengujian hipotesis kedua menunjukkan bahwa variabel sanksi perpajakan berpengaruh positif terhadap kepatuhan pelaporan wajib pajak orang pribadi. Nilai t hitung variabel sanksi perpajakan adalah sebesar 1,116 dan nilai $p$ value sebesar $0,047<0,05$ yang artinya berpengaruh positif. Hal ini menunjukkan bahwa hipotesis diterima.Hasil uji ini konsisten dengan penelitian yang dilakukan oleh Arum (2012).Sanksi perpajakan berpengaruh postif terhadap kepatuhan pelaporan wajib pajak. Artinya semakin tegas sanksi yang diberikan akan membuat wajib pajak tersebut semakin patuh.

Hasil pengujian hipotesis ketiga menunjukkan bahwa variabel penerapan sistem e-filing berpengaruh positif terhadap kepatuhan pelaporan wajib pajak orang pribadi. Nilai t hitung variabel penerapan sistem e-filing adalah sebesar 
2,280dan nilai $p$-value sebesar $0,025<0,05$ yang artinya berpengaruh positif . Hal ini menunjukkan bahwa hipotesis diterima.Hasil uji ini konsisten dengan penelitian yang dilakukan oleh Nurhidayah (2015), yang menyatakan bahwa penerapan $e$-filing berpengaruh positif terhadap kepatuhan wajib pajak.Penelitian ini juga sejalan dengan penelitian yang dilakukan oleh Wulandari (2016).

Hasil pengujian hipotesis keempat menunjukkan bahwa variabel pengetahuan tax amnesty berpengaruh positif terhadap kepatuhan pelaporan wajib pajak orang pribadi. Nilai t hitung variabel pengetahuan tax amnesty adalah sebesar 3,694 dan nilai $p$-value sebesar 0,000 < 0,05 yang artinya berpengaruh positif. Hal ini menunjukkan bahwa hipotesis diterima.Hasil uji ini konsisten dengan penelitian yang dilakukan olehJacques (2010).Tax amnesty berpengaruh postif terhadap tingkat kepatuhan wajib pajak.Artinya tax amnesty dapat meningkatkan penerimaan pajak serta meningkatkan kepatuhan pajak.

\section{SIMPULAN}

Simpulan dalam penelitian ini adalah sebagai berikut; 1) Kesadaran wajib pajak berpengaruh positif dan signifikan terhadap kepatuhan pelaporan WPOP di KPP Pratama Denpasar Timur.Tingkat kesadaran wajib pajak yang semakin meningkat akan diikuti dengan peningkatan kepatuhan pelaporan WPOP di KPP Pratama Denpasar Timur; 2) Sanksi perpajakan berpengaruh positif dan signifikan terhadap kepatuhan pelaporan WPOP di KPP Pratama Denpasar Timur. Pemberian sanksi perpajakan yang semakin tegas dapat meningkatkan kepatuhan pelaporan WPOP di KPP Pratama Denpasar Timur; 3) Penerapan sistem e-filing berpengaruh positif dan signifikan terhadap kepatuhan pelaporan WPOP di KPP 
Pratama Denpasar Timur.Semakin tingginya kemudahan yang diberikan dengan adanya sistem $e$-filing bagi WPOP, juga menyebabkan peningkatan kepatuhan pelaporan WPOP di KPP Pratama Denpasar Timur; 4) Pengetahuan tax amnesty berpengaruh positif dan signifikan terhadap kepatuhan pelaporan WPOP di KPP Pratama Denpasar Timur. Jika WPOP memiliki pengetahuan mengenai tax amnesty, akan memberikan dorongan kepatuhan bagi WPOP untuk melaporkan jumlah wajib pajak yang dimilikinya.

Berdasarkan hasil penelitian dan simpulan di atas, maka saran yang dapat diberikan adalah sebagai berikut. 1) Berdasarkan penelitian ini, program tax amnesty telah membuat wajib pajak lebih patuh dalam melaporkan kewajiban perpajakannya. Kepatuhan wajib pajak dalam melaporkan harta yang kurang ataupun belum dilaporkan, dapat meningkatkan pendapatan negara. Bagi Direktorat Jendral Pajak sebagai lembaga yang ditugaskan melaksanakan pemungutan pajak, telah melaksanakan tugasnya dengan baik; 2) Penelitian selanjutnya disarankan membuat izin menyebar kuesioner di Kantor Kesatuan Bangsa dan Politik, dan setelah mendapat izin dapat menyebarkan kuesioner di Satuan Kerja Perangkat Daerah (SKPD) yang telah dipilih sebelumnya. Tujuan dibuatnya surat izin tersebut agar peneliti lebih mudah untuk mendapatkan responden. Penelitian selanjutnya juga dapat mengembangkan penelitian ini kembali dengan meneliti variabel lain yang dapat memengaruhi kepatuhan pelaporan WPOP.

\section{REFERENSI}

Agus, Jatmiko. 2006. Pengaruh Sikap Wajib Pajak pada Pelaksanaan Sanksi Denda, Pelayanan Fiskus, dan Kesadaran Perpajakan Terhadap Kepatuhan 
Luh Putu Santi Krisna dan Ni Ketut Lely Aryani M. Pengaruh...

Wajib Pajak Studi Empiris Terhadap Wajib Pajak Orang Pribadi di Kota Semarang. Unisversitas Diponegoro: Tesis Megister Akuntansi.

Ajzen, Icek. 1991. The Theory of Planned Behavior. Organizational Behavior and Human Decision Process, Vol.50

Ali et al. 2001. The Effects of Tax Rates and Enforcement Polices on Tax Payer Complienace: A Study of Self Employed Tax Payers. Antlantic Economic Journal, 29 (2)

Arum, Harjanti Puspa. 2012. Pengaruh Kesadaran Wajib Pajak, Pelayanan Fiskus, dan Sanksi Pajak terhadap Kepatuhan Wajib Pajak Orang Pribadi yang Melakukan Kegiatan Usaha dan Pekerjaan Bebas (Studi di Wilayah KPP Pratama Cilacap). Skripsi Sarjana (S1) Fakultas Ekonomika dan Bisnis, Universitas Diponegoro.

Astana, Wayan Sugi dan Lely Aryani M, Ni Ketut. 2017. Pengaruh Penerapan Sistem Administrasi Perpajakan Modern dan Kesadaran Wajib Pajak pada Kepatuhan Wajib Pajak. E-Jurnal Akuntansi Universitas Udayana, 18(1), $\mathrm{h}: 818-846$

Chau, Liung. 2009. A Critical Review of Fischer Tax Compliance Model (A Research Syntesis). Journal of Accounting and Taxation, 1(2):p:34-40.

Cronin, J. Joseph, Steven A. Taylor. 1992. Measuring Service Quality. Journal of Marketing, 56: p: 55-68.

Desmayanti, E. (2012). Faktor-Faktor yang Mempengaruhi Penggunaan Fasilitas E-Filing Oleh Wajib Pajak Sebagai Sarana Penyampaian SPT Masa Secara Online dan Realtime (Kajian Empiris di Wilayah Kota Semarang). Jurnal Akuntansi, 1(1)

Dewinta, Rinta Mulia dan Syafruddin. 2012. Pengaruh Persepsi Pelaksanaan Sensus Pajak Nasional dan Kesadaran Perpajakan terhadap Kepatuhan Wajib Pajak di Lingkungan Kantor Wilayah Direktorat Jendral Pajak Daerah Istimewa Yogyakarta. Diponegoro journal of accounting. Vol. 1. Nomor 2 Tahun 2012.

Doran, Michael. 2009. Tax Penalties and Tax Compliance, Harvard Journal on Legislation (www.ssrn.com), Vol.46:p:111-161.

Faisal, Gaton S.M. 2009. How to be A Smarter Taxpayer. Bagaimana Menjadi Wajib Pajak. Jakarta: Grasindo.

Finch, R. Curtis and Robert, L. McGough. 1982. Administering and Supervising Occupational Education, Prentice-Hall, Inc., Englewood Cliffs, New Jersey 
Fuadi, Arabella Oentari dan Yenni Mangoting. 2013. Pengaruh Kualitas Pelayanan Petugas Pajak, Sanksi Perpajakan, dan Biaya Kepatuhan Pajak terhadap Kepatuhan Wajib Pajak UMKM. Tax and Accounting Review, Vol 1(1) p:18-27.

Ghozali, Imam. 2016. Aplikasi Analisis Multivariate dengan Program SPSS. Semarang: Universitas Diponegoro.

Jacques, Malherbe. 2010. "Tax Amnesties in ghe 2009 Landscape”. Dalam Inside Tax Magazine Edisi 34.

James, Simon dan Clinton Alley.2004. Tax Compliance, Self-Assesment and Tax Adminstration. Journal of Finance and Management in Public Service

Jung, Woon Oh. 1999. Taxpayer Disclousure and Penalty Laws. Seoul National University. Journal of Public Economics Theory. Vol 2(2), p:151-742.

Junpath, Sachin. 2013. Multiple Tax Manesties and Compliance in South Africa. Durban University of Technology.

Mardiasmo. 2016. Perpajakan. Edisi Terbaru 2016. Yogyakarta: Andi.

Muliari, Ni Ketut; Ery Setiawan, Putu.Pengaruh Persepsi tentang Sanksi Perpajakan dan Kesadaran Wajib Pajak pada Kepatuhan Pelaporan Wajib Pajak Orang Pribadi Di Kantor Pelayanan Pajak Pratama Denpasar Timur. Jurnal Ilmiah Akuntansi dan Bisnis, [S.1.], jan. 2011. ISSN 2303-1018. Available at: <https://ojs.unud.ac.id/index.php/jiab/article/view/2641>. Date accessed: 09 july 2017. h:1-23.

Mustikasari, Elia. 2007. Kajian Empiris tentang Kepatuhan Wajib Pajak Badan di Perusahaan Industri Pengolahan di Surabaya. Jurnal Simposium Nasional Akuntansi.

Norasmila Awang and Azlan Amran. "Ethics and Tax Compliance" In Ethics, Governance and Corporate Crime: Challenges and Consequences. Published online: 08 Oct 2014; 105-113.

Nurhidayah, Sari (2015). Pengaruh Penerapan System E-Filing terhadap Kepatuhan Wajib Pajak dengan Pemahaman Internet sebagai Variabel Pemoderasi pada KPP Pratama Klaten.Skripsi Program Studi Akuntansi Universitas Negeri Yogyakarta.

Parmita Saha, Atanu K. Nath, Esmail Salehi-Sangari. 2012. Evaluation of Government E-Tax Websites: An Information Quality and System Quality Approach. Transforming Government: People, Process, and Policy, Vol. 6 Issue: 3, pp.300-321, https://doi.org/10.1108/17506161211251281 
Palil, M. Rizal. 2005. Does Tax Knowledge Matter in Self Assessment System? Evidence from Malaysia Tax Administrative.The Journal of American Academy of Bussiness, 2. Cambridge.

Punarbhawa, B dan Aryani M, Ni Ketut Lely. 2013. Pengaruh Reformasi Administrasi Perpajakan dan Pengetahuan Perpajakan terhadap Tingkat Kepatuhan Pengusaha Kena Pajak (PKP). E-Jurnal Akuntansi Universitas Udayana, 5(2), h:381-397.

Riahi, Ahmed. 2004. Relationship Between Tax Compliance Internationally and Selected Determinants of Tax Moral. Journal of International Accounting, Auditing and Taxation, Vol 13, p:135-143.

Suyanto, Suyanto; Intansari, Pasca Putri Lopian Ayu; Endahjati, Supeni. Tax Amnesty. Jurnal Akuntansi, [S.I]

Supadmi, 2009. Meningkatkan Kepatuhan Pajak Melalui Kualitas Pelayanan. AUDI Jurnal Akuntansi dan Bisnis. Vol. 2.

Togler, B. 2005. Direct Democracy and Tax Morale. European Journal of Political Economy, Vol 21(3), h:525-531.

Webley, P., H. Robben., H. Elffers dan D. Hessing. 1991. Tax Evasion: An Experimental Approach. Cambridge, United Kingdom: Cambridge University Press

Wulandari. 2016. Pengaruh Penerapan E-Filing, Tingkat Pemahaman Perpajakan, dan Kesadaran Wajib Pajak terhadap Kepatuhan Wajib Pajak di KPP Pratama Yogyakarta. Skripsi Sarjana (S1) pada Fakultas Ekonomi Negeri Yogyakarta.

Yulitasari, Inten dan Suprasto, Herkulanus Bambang. 2017. Pengaruh Tanggung Jawab Moral, Sanksi Perpajakan, dan Penerapan Sistem E-Filing pada Kepatuhan Pelaporan Wajib Pajak. E-Jurnal Akuntansi Universitas Udayana, 20(2), h:1360-1389. 